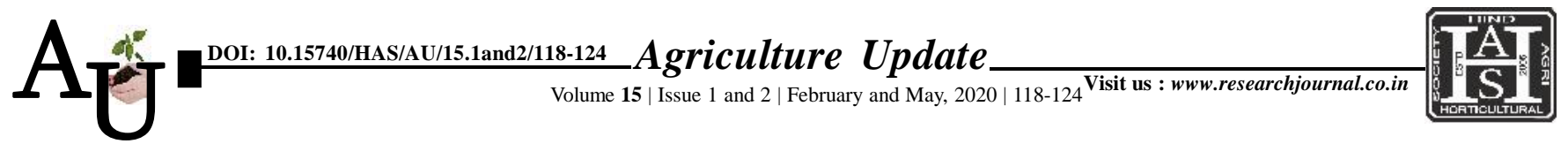

ISSN-0973-1520

A Case STudy :

\title{
Value chain study of handicraft in Barmer district of Rajasthan
}

\author{
Pradeep Pagaria and Sonali Sharma
}

Article Chronicle: Received :

10.04.2020;

Accepted :

27.04.2020

KEY WoRDS:

Handicraft, Value

chain, Livelihood,

Artisian

SUMMARY : Barmer district is situated in western part of Rajasthan state. Barmer is the second largest district of Rajasthan. Rajasthan is the important state in the country as far as handicraft sector is concerned. Considering the drought situation which exists almost every year, it is one sector which can provide huge employment and alternate income to rural mass. The exports of handicrafts from Rajasthan in 2003-2004 stood at Rs. 1800 crores as against 1200 crores in the previous year, with a growth rate of 33 per cent. The export of zari and zari goods, which was 57.19 crore in 1994-95, increased to 210.54 crore by 2003-04. Every district has its distinctive handicrafts and over 7 lac craft persons are employed in this activity. Thus, their is a immense scope for livelihood enhancement through handicraft and marketing in Barmer district.

How to cite this article : Pagaria, Pradeep and Sharma, Sonali (2020). Value chain study of handicraft in Barmer district of Rajasthan. Agric. Update, 15(1 and 2): 118-124; DOI : 10.15740/HAS/AU/15.1and2/118-124. Copyright@ 2020: Hind Agri-Horticultural Society.

Author for correspondence :

Email: P_Pagaria@

yahoo.com

See end of the article for authors' affiliations 